\title{
Economic viability of a crop-livestock integration system
}

\author{
Marcela de Mello Brandão Vinholis ${ }^{*}$ (D) Hildo Meirelles de Souza Filho ${ }^{\text {iD }}$ Isabela Shimata $^{2}$ (D) \\ Patricia Perondi Anchão Oliveira ${ }^{1(D)}$ André de Faria Pedroso ${ }^{1}$ (D)
} ${ }^{1}$ Empresa Brasileira de Pesquisa Agropecuária (Embrapa), 13560-970, São Carlos, SP, Brasil. E-mail: marcela.vinholis@embrapa.br.
${ }^{*}$ Corresponding author.

${ }^{2}$ Departamento de Engenharia de Produção, Universidade Federal de São Carlos (UFSCar), São Carlos, SP, Brasil.

\begin{abstract}
Crop monoculture and single conventional cattle raising were designed for a rapid increase in productivity and food supply. However, some of these production systems have shown signs of saturation and negative environmental impacts. Crop-livestock integration systems have been developed as an alternative that delivers increased productivity and greater environmental sustainability. This article presents an evaluation of the economic viability and the financial risk associated with an investment in crop-livestock integration with a focus on the production of beef cattle in São Carlos, SP, Brazil. Results showed that the investment is economically viable and has an Internal Rate of Return higher than that of a conventional system. Monte Carlo simulations showed that the integrated system presents lower market risks when compared to the conventional system.
\end{abstract}

Key words: integrated production system, investment analysis, Monte Carlo simulation.

Viabilidade econômica de um sistema de integração lavoura-pecuária

RESUMO: A produção agrícola em monocultivo e a pecuária convencional não integrada com culturas foram desenhadas para um aumento rápido da produtividade e da oferta de alimentos. Entretanto, alguns destes sistemas de produção têm mostrado sinais de saturação e impactos ambientais negativos. Sistemas de integração lavoura-pecuária têm sido desenvolvidos como uma alternativa que oferece aumento de produtividade e maior sustentabilidade ambiental. O presente trabalho tem por objetivo estimar a viabilidade econômica e o risco financeiro associado a um projeto de investimento em integração lavoura-pecuária com foco para a produção de animais de corte em São Carlos, SP. Os resultados mostraram que o investimento é economicamente viável e apresenta Taxa Interna de Retorno superior à de um sistema convencional. Por meio da simulação de Monte Carlo constatou-se o sistema integrado apresenta menores riscos de mercado quando comparado com o sistema convencional.

Palavras-chave: sistema de produção integrado, análise de investimento, simulação de Monte Carlo.

\section{INTRODUCTION}

The growing demand for food and the technological evolution have led modern agriculture to simplified models of monoculture which are intensive in the use of agricultural inputs and standardized, leaving aside the association (integration) of crops and of crops with livestock (BALBINO et al., 2011). These crop production models are showing signs of saturation. Parallel to that, in the cattle raising activity in Brazil, which is predominantly based on pastures, still coexists capital-intensive production systems with high yields per area and/or per animal, and extensive systems with low technical efficiency, characterized by pasture and soil with some degree of degradation, low replacement of soil nutrients and low investment in technology (ZYLBERSZTAJN \& MACHADO FILHO, 2003; SOUZA FILHO et al., 2010).

Crop-livestock integrated (CLI) systems are presented as alternatives to traditional farming for the maintenance or increment in productivity and indirect recovery of pastures. In these systems, crops are not introduced as eventual components but are part of a system in which the production of grains and animals interact and complement each other in aspects such as soil management, fertility, physics and biology, improving farm profitability and bringing social advancements to rural areas (MACEDO, 2009). Crop-livestock integrated systems are characterized by the rotation, consortium or succession of crop and livestock production activities in the same area, in a harmonious way, in 
order to benefit both activities. These systems make possible to explore economically the production areas in a year-round basis, allowing increased production of grains, milk and meat, at lower costs as a result of crop and pasture interaction. The objective of CLI systems is to produce more in the combined system than it would be produced in dissociated crop and livestock systems.

Integrated crop-livestock systems are based on the premise that the cattle raising activity may contribute with organic residues, improvement in physical and chemical soil characteristics, rotation of cultures, interruption of plant disease cycles and reduction of losses resultant of weather variability. Besides that, these systems may provide fresh and highly nutritive forages to cattle, inclusive in winter, while in other systems forage may be scarce.

Environmental benefits may result from CLI systems including, improvements in soil chemical, physical and biological characteristics. Considering soil chemical properties, fertility is improved through recycling of nutrients and more efficient use of fertilizers resultant from the different necessities of cultures in rotation. Soil physical properties are improved by forage roots which improve structure, water infiltration and retention capacity and carbon stock in the soil. Consequently, there is an increment in density and abundance of soil fauna and other biological attributes (MACEDO, 2009). Being technically viable is not enough for decision-making on the CLI adoption. Economic viability of these systems must also be considered. Some studies demonstrated the economic viability of CLI in Goiás and other states in the Cerrado area of Brazil (MAGNABOSCO et al., 2009; MARTHA JÚNIOR et al., 2011), in which the focus was the commercialization of grains. Nonetheless, there are other possibilities involving crop and livestock association. LAZZAROTTO et al. (2009) and LAZZAROTTO et al. (2010) and SILVA et al. (2012) observed that crop-beef cattle integrated systems in Paraná State presented positive and better economic results compared with systems specialized in grain or beef cattle production. MAGNABOSCO et al. (2009) reported that CLI systems in Goiás state, in which the Santa Fé method was used for pasture establishment, were considered economically attractive and presented low risk. GARCIA et al. (2012) obtained positive economic results for CLI systems in which corn was cultivated in rotation with Panicum and Brachiaria pastures in Mato Grosso do Sul State. In Mato Grosso, CLI systems have also been considered an alternative to mitigate risks, with viable economic results (REIS et al., 2019). Empirical studies involving the analysis of economic viability of CLI systems in the São Paulo state could not be found.

Considering the scarcity of data on the subject, this study aimed to evaluate the economic viability and the financial risk of CLI system in which crop production (corn) is used for animal feed (silage). A ten years cash flow was estimated using data from an experimental research carried out by EMBRAPA Pecuária Sudeste, Brasil. The estimated Net Present Value and Internal Rate of Return, along with a Monte Carlo risk analysis, indicated that the system is economically viable. In addition to this introduction, the next section contains the methodology, followed by discussion of results and final considerations.

\section{METHODOLOGY}

\section{Characterization of the CLI system}

The technical coefficients used in this study were obtained in an experimental CLI system implemented at Embrapa's Southeast Livestock Center, São Carlos, SP, from 2012 to 2016. The climate is tropical of altitude and the soil is a redyellow dystrophic argisol, medium / clayey texture. The 6 ha experimental area was divided in three equal parts ( 2 ha each) cultivated with Brachiaria cv. Piatã and corn in rotation. The investments in infrastructure (fences, water and feed troughs) were made in 2012 (year zero). Productive activities were monitored during seasons 2013/2014, 2014/2015 and 2015/2016, considered years 1,2 and 3 in the cash flow analysis. Figure 1 illustrates the three rotational cycles, from November 2013 to February 2016. In each of those cycles, one third of the area was cultivated with corn and two-thirds with pastures for beef cattle production. At the end of each cycle, the corn production was moved to the next third of the area.

Corn was annually sown in November and harvested in March (summer crop). The cattle raising activity comprehended the growing and finishing phases. In each agricultural year, 18 months old steers, weighing $9.5 @(285 \mathrm{~kg})$ on average, are bought from October to December, in quantities compatible with forage availability in the pastures, and finished on pasture until October to November of the next year. At the end of each cycle, the fat steers are sold for slaughter. Animals were supplemented with a mineral mix during summer (rainy season) and with a mineral/concentrate/urea mix (protein salt $-30 \%$ crude protein) during winter (five months). Pastures were managed under rotational stocking 


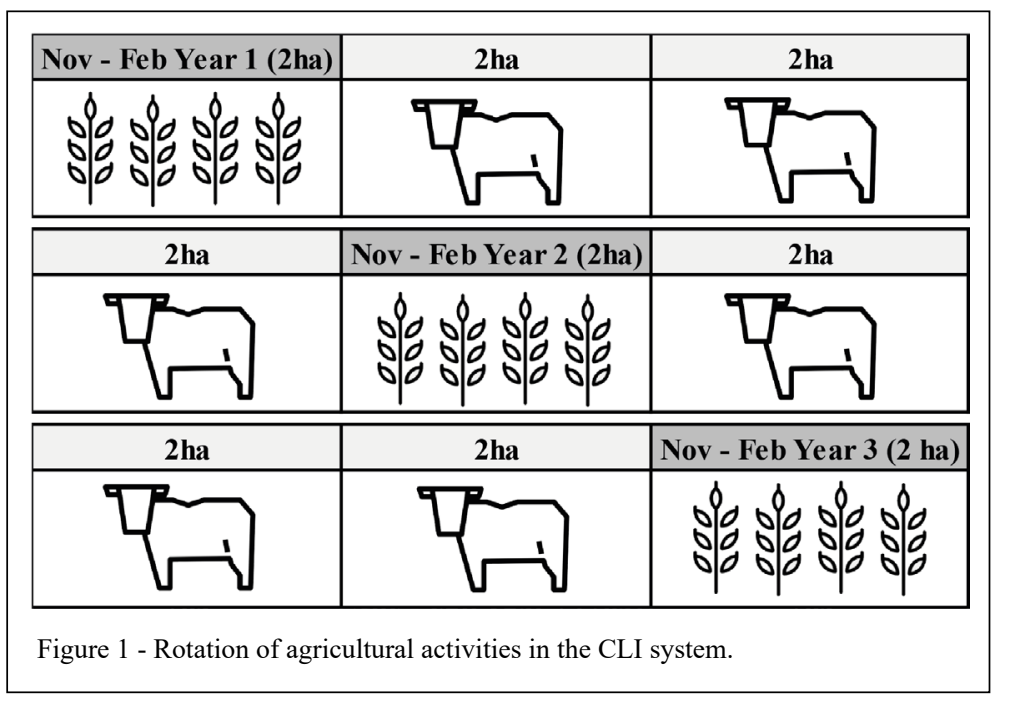

with four nitrogen fertilizations during summer (150 $\mathrm{kg}$ urea/ha per application). Vaccination followed the official calendar; endoparasites were controlled at six months intervals and ectoparasites were controlled according to necessity.

Indicators of economic viability and the financial risk of CLI system were estimated and compared with the ones of a Conventional Cattle (CC) system. Technical coefficients for the latter were obtained from conventional cattle raising system which was carried out in 6 ha of the same EMBRAPA's Center during the same period of CLI experiment. In the year zero of this experiment, the pasture was recovered by non-tillage method (ANDRADE et al., 2015). Zootechnical and pasture management practices adopted in the CLI system was also adopted in the CC system.

\section{Indicators of economic viability and Monte Carlo simulation}

An annual cash flow was constructed to obtain economic viability indicators for each system, CLI and CC. This cash flow presents the monetary amounts referring to revenues, operating cost and investment for a period of ten years (SANTOS \& MARION, 1996). The sale of products is registered as revenue in cash flow, while operating cost refers to expenses in the production process with input acquisition, labor, maintenance of machinery, rent, etc. Investment refers to machinery acquisition and infrastructure, which have the potential of bringing benefits for many years. Depreciation is a cost item but it is not money disbursement. It does not participate directly in the cash flow but it is necessary for the calculus of the residual value of depreciating assets in the project (machinery, implements and infrastructure).

Primary and secondary data set allowed the elaboration of the cash flow for the CLI system. The year zero considered the investments in infrastructure (water troughs, fences, etc), machinery and farm implements. Technical coefficients from the experiment were used to estimate the cash flow from Year 1 to Year 3. The average values from the three first years were then used to project values for the following years until Year 10. Residual values for infrastructure and the proportional residual value for the use of machinery, implements and infrastructure were included in Year 10 (Table 1).

The analysis was made using the Net Present Value (NPV) and the Internal Rate of Return (IRR) as indicators (NORONHA \& DUARTE, 1995; CASAROTTO FILHO \&KOPITTKE, 2000). The

Table 1 - Residual values for infrastructure, machines and implements.

\begin{tabular}{|c|c|c|}
\hline Group & Item & Residual value \\
\hline \multirow{5}{*}{ Infrastructure } & Hydraulic equipment & $20 \%$ \\
\hline & Water trough & $20 \%$ \\
\hline & Electric fence & $37 \%$ \\
\hline & Boundary fence & $37 \%$ \\
\hline & Salt trough & $20 \%$ \\
\hline \multicolumn{2}{|c|}{--------------Farm implements--------------- } & $10 \%$ \\
\hline
\end{tabular}

Ciência Rural, v.51, n.2, 2021. 
NPV is defined as the algebraic sum of net cash flows adjusted to the present at discount rate $\mathrm{i}$, according to the equation:

$\operatorname{NPV}(i)=\sum_{j=0}^{n} \frac{C F_{j}}{(1+i)^{j}}$

where, $\mathrm{i}=$ discount rate. In this article, $\mathrm{i}$ assumed the value of the real interest rate (4.96\% per year), which is the Brazilian basic interest rate (Selic) deflated by the Extended National Consumer Price Index (IPCA) of Nov 2017;

$\mathrm{j}=$ cash flow period;

$\mathrm{CF}_{\mathrm{j}}=$ net cash flow value for $\mathrm{t}=0, \ldots, \mathrm{n}$;

$\mathrm{n}=$ number of flow periods.

The acceptance of investment, based on the NPV, follows the criteria (MARTINELLI et al., 2019; RICHARDSON et al., 2014): NPV > $0=$ the investment is economically attractive; NPV $=$ $0=>$ the investment is indifferent; NPV $<0 \Rightarrow>$ the investment is not economically attractive.

The IRR is calculate using the equation (MOTTA \& CALÔBA, 2002):

$\operatorname{IRR}(i)=\sum_{j=0}^{n} \frac{C F_{j}}{(1+i)^{j}}=0$

Where $i$ is the Internal Rate of Return, which returns an NPV equal to zero.

The interpretation of IRR for the acceptance of the project is done by comparison with a hurdle rate. If IRR is higher than the hurdle rate, the investment is considered economically attractive.
Otherwise, the investment is not economically attractive. Its economic return is surpassed by an investment with lower risk. If IRR is equal to the hurdle rate, the situation is considered as indifferent. In this article, we used the real interest rate, $4.96 \%$ per year, as the hurdle rate. We also estimated IRR of CC system in order to compare with that of the CLI system.

NPV and IRR have a deterministic nature because the cash flow projection is known and kept constant. The cash flow projection is associated to the risk of variations of the market prices, for both product sales and acquisition of agricultural inputs. The economic environment is complex and subject to uncertainty, which requires additional technique in order to consider risk in the analysis (MACEDO et al., 2017). Therefore, we introduced the risk associated with economic viability of CLI system and CC system by using Monte Carlo Simulation (MCS) combined with Spearman correlation between random variables. The analysis followed three main steps presented in Figure 2.

In the first step, CLI system and CC system were described and deterministic 10-year cash flows were created in a spreadsheet. The cash flows comprise corn silage revenue, finished steers revenue, and expenditure with infrastructure, machinery and operations of the joint production corn and beef cattle. The NPV was then calculated from the net cash flow.



Ciência Rural, v.51, n.2, 2021. 
The second step consisted of introduction of risk into analysis. The stochastic simulation model is used to analyze decisions involving risk, that is, a model in which the evolution of one or more factors is uncertain. For this, a sensitivity analysis was performed to investigate the sensitivity of NPV to the prices of: finished steer, corn, steer, fertilizers, land lease and labor. The prices of steer, fertilizers, land lease and labor were chosen because these inputs costs have high share in the total expenditure of both systems. The effect of $10 \%$ increase or decrease in one of these prices on economic performance was investigated, while all other prices were kept constant (KAMALI et al., 2016; FIGUEIREDO et al., 2006). In CLI system, were ported that $10 \%$ increase in steer price reduced NPV by $97.12 \% ; 10 \%$ decrease in corn price reduced NPV by $43.79 \%$; and $10 \%$ decrease in finished steer price reduced NPV by $164.95 \%$, which became negative, ceteris paribus. In CC system, the NPV became negative with $10 \%$ of variation in the steer price or in the finished steer price. Other prices presented lower effect on the NPV of both systems. Therefore, steer price, finished steer price and corn price were chosen as random variables in the Monte Carlo Simulation, in which they are described by a probability distribution function (MOORE \& WEATHERFORD, 2005).

The prices of 18-month-old steers, maize and finished steers, from 2010 to 2017 , were used to estimate the probability distribution of each random variable and the Spearman correlation between them. The data was obtained from the Center for Advanced Studies in Applied Economics (CEPEA, 2017) and Scot Consulting (2017). Steers and finished steers prices, from October to December of each year, were used in the estimation. Purchase of steers and sale of finished steers were modeled for these months. Corn prices refer to the months of May to October, the dry season, when beef cattle feedlots demand silage more intensively. The price of corn silage is difficult to determine because lack of quoted market prices. Therefore, we estimated it by taking the price of corn grain as reference and assuming $175 \mathrm{~kg}$ of dry corn grain in one ton of corn silage
(BEEFPOINT, 2017). All prices were deflated by the Price for Consumers Index (IPCA). The KolmogorovSmirnov statistic (CARGNELUTTI FILHO et al., 2004) guided the decision on the fit of probability distribution to database.

In sequence, the parameters of the probability distributions of the random variables were stablished. The estimated minimum values of probability distributions were used as the worst scenario, while the estimated maximum values were used as the best scenario. The deterministic values that were used in the 10 -year cash flow were considered the most likely values, as presented in table 2. The Spearman correlation between steer price and finished steer price was 0,8962. In such case, Monte Carlo simulation combined with Spearman's correlation is recommended (PACHECO et al., 2014; PACHECO et al., 2017).

The third step consists of the Monte Carlo Simulation. Microsoft Excel ${ }^{\circledR}$ from Microsoft Office $^{\circledR}$ and @ Risk ${ }^{\circledR}$ from Palisade were used to repeat the 10-year cash flow 1000 times (iterations), considering different stochastic prices for each year. The model simulates several combinations of the random variables based on their respective probabilities, including the best and worst scenarios. As a result, the model estimates 1000 points for an empirical probability distribution of the NPV, which showed the range of risk associated with the economic performance. Histogram of the frequency of the NPV values (random scenarios) allows for the analysis of the probability distribution.

Technical coefficients used in deterministic cash flow
Primary data on quantities of inputs were recorded in field spreadsheets during the experimental period (2012-2016), allowing the calculation of technical coefficients and estimation of production costs for the CLI system (Table 3). Prices of agricultural inputs and products were obtained from Embrapa and in secondary sources such as Institute of Agricultural Economics (IEA, 2017) and

Table 2 - Parameters of probability distribution of the random variables used in the Monte Carlo simulation.

\begin{tabular}{|c|c|c|c|c|c|}
\hline Random variable & Most likely & Min. & Max. & Probability distribution & $\mathrm{K}-\mathrm{S}^{*}$ \\
\hline Price of Silage $(\mathrm{R} \$ / \mathrm{t})$ & 124.10 & 90.60 & 157.50 & Triangular & 0.1023 \\
\hline Price of carcass (R\$/@ of finished steer) & 146.68 & 129.85 & 172.60 & Pert & 0.0965 \\
\hline Price of steers (R\$/head) & 1570.00 & 1315.00 & 1907.00 & Triangular & 0.1037 \\
\hline
\end{tabular}

Note. "Kolmogov-Smirnov test. 
Center for Advanced Studies in Applied Economics (CEPEA, 2017).

Selling of both finished steers and corn silage provided the revenue of the CLI system, while the revenue of CC system is obtained from the selling of finished steers only. The technical coefficients necessary for revenue estimation in the CLI system and in the CC system are in Table 4. Carcass yield in CLI system was $53.9 \%$ on average, and in CC system was $54.43 \%$.

\section{RESULTS AND DISCUSSION}

The estimated cash flow for the CLI system is presented in table 5 . The year 0 represents the year of investments in infrastructure, such as building of fences in the perimeter of the area and division fences for the rotational management of the pasture, installation of water troughs and troughs for mineral mix, liming of the total area and machinery and farm implements. For these, it was calculated the proportional value to their use during the 10 years duration of the project. For example, the investment value on machinery and farm implements considered the hours of use during the term of the project. A total of $\mathrm{R} \$ 32,079.52$ was obtained for the initial investment. The investment value and the residual value of machinery and farm implements were calculated proportionally to the hours of use during the period of the Project.

Starting in year 1 , one third of the area (2 ha) was annually cultivated with corn for silage. It can be noticed in table 5 that the cost of the corn crop, not considering machinery repair and land lease, was $\mathrm{R} \$ 5,532.63$ in total, or $\mathrm{R} \$ 2,766.32$ per ha. The same technology package considered for the corn crop was replicated in all years of the cash flow. However, adverse weather conditions affected production, as in the dry period of the 2013/2014 agricultural year. These variations in production are reflected in the revenues from silage sales. In the other two thirds of the area (4ha) pastures were managed in the rotational stocking method for finishing the steers. The item with the higher influence over the cost of cattle finishing on pasture is the purchase of steers. The impact of this item on the total cost of the livestock production varied between $68 \%$ and $72 \%$, not considering machinery repair and land lease. This variation resulted from differences in the stocking capacity of the pasture during the experiment, according to table 4 . The stocking capacity is defined

Table 3 - Technical coefficients of the CLI system (6 ha), amount of inputs per year.

\begin{tabular}{|c|c|c|c|c|c|c|c|c|c|c|}
\hline \multirow{2}{*}{$\begin{array}{l}\text { Annual inputs for the } \\
\text { CLI system ( } 6 \text { ha: } 2 \text { ha } \\
\text { corn and } 4 \text { ha pasture) }\end{array}$} & \multirow{2}{*}{$\begin{array}{c}\begin{array}{c}\text { Labor } \\
\text { (h) }\end{array} \\
\text { Tractor } \\
\text { operator }\end{array}$} & \multirow{2}{*}{$\begin{array}{c}\text { Silage } \\
\text { equipment }\end{array}$} & \multirow[b]{2}{*}{$\begin{array}{l}\text { Fertilizer } \\
\text { applicator }\end{array}$} & \multirow[b]{2}{*}{$\begin{array}{l}\text { Sowing } \\
\text { equipment }\end{array}$} & \multirow[b]{2}{*}{$\begin{array}{l}\text { Sprayer } \\
(600 \mathrm{~L})\end{array}$} & \multirow[b]{2}{*}{$\begin{array}{l}\text { Corn } \\
\text { planting } \\
\text { machine }\end{array}$} & \multirow[b]{2}{*}{$\begin{array}{l}\text { Tractor } \\
(85 / 90 \\
\text { HP })\end{array}$} & \multirow[b]{2}{*}{$\begin{array}{l}\text { Corn } \\
\text { harvester } \\
\text { (1line) }\end{array}$} & \multirow[b]{2}{*}{$\begin{array}{c}\text { Tractor } \\
(120 \\
\text { HP) }\end{array}$} & \multirow[b]{2}{*}{$\begin{array}{l}\text { Silage } \\
\text { wagon }\end{array}$} \\
\hline & & & & & & & & & & \\
\hline \multicolumn{11}{|l|}{1 - Operation } \\
\hline $\begin{array}{ll}\text { NPK } & \text { fertilizer } \\
\text { application } & \end{array}$ & 3 & - & 3 & - & - & - & 3 & - & - & - \\
\hline Herbicide application & 3 & - & - & - & 3 & - & 3 & - & - & - \\
\hline Urea application & 6 & - & 6 & - & - & - & 6 & - & - & - \\
\hline Sowing of Piatã seeds & 1.5 & - & - & 1.5 & - & - & 1.5 & - & - & - \\
\hline Cultivation of corn & 2.5 & - & - & - & - & 2.5 & 2.5 & - & - & - \\
\hline Harvesting of corn & 3 & - & - & - & - & - & 3 & 3 & - & - \\
\hline Ensiling of corn & 2 & 2 & - & - & - & - & - & - & 2 & - \\
\hline Transport & 4 & - & - & - & - & - & 4 & - & - & 4 \\
\hline Total of hours & 25 & 2 & 9 & 1.5 & 3 & 2.5 & 23 & 3 & 2 & 4 \\
\hline 2 -Inputs & & Quantity & & & & & & & & \\
\hline Corn seeds & & 40 & $\mathrm{~kg}$ & & & & & & & \\
\hline Herbicide & & 10 & $\mathrm{~L}$ & & & & & & & \\
\hline Fertilizer (08-28-16) & & 1000 & $\mathrm{~kg}$ & & & & & & & \\
\hline Fertilizer (20-05-20) & & 1000 & $\mathrm{~kg}$ & & & & & & & \\
\hline Piatã seeds & & 16 & $\mathrm{~kg}$ & & & & & & & \\
\hline Urea & & 2400 & $\mathrm{~kg}$ & & & & & & & \\
\hline
\end{tabular}


Table 4 - Technical coefficients of the CLI system and the CC system ( 6 ha of each system). ${ }^{*}$

\begin{tabular}{lccc}
\hline Year & Stocking rate (heads of steer) & Carcass (@, finished steer) & Silage (t) \\
\hline 1 & 16 & 274.68 & 73 \\
\hline 2 & 12 & 232.73 & 93.12 \\
\hline 3 & 14 & 256.41 & 80.04 \\
\hline Mean (Year 4-10) & 14 & 254.61 & - \\
\hline 2 & 19 & 391.50 & - \\
\hline 3 & 16 & 288.42 & - \\
\hline Mean (Year 4-10) & 18 & 337.98 & - \\
\hline
\end{tabular}

${ }^{*}$ Note. Technical coefficients were obtained from an experiment carried out during the seasons 2013/2014, 2014/2015 and 2015/2016 by Embrapa, São Carlos, SP.

by the dry matter production in the pasture, which is influenced by weather conditions. The other items in the livestock production cost also vary according to the number of animals finished annually. The average cost of finishing beef cattle on pasture in the 4 ha experimental area, excluding the steers acquisition, machinery repair and land lease, was R\$ 9,190.96 per year, that is, $\mathrm{R} \$ 2,297.74$ per ha of pasture. The average cost of finishing per animal was R\$ 664.17 per agricultural year.

The average of the total cost in the CLI system was R $\$ 41,524.60$ per agricultural year. That means a cost of $R \$ 6,920.77$ per ha. The item with the higher impact over this value is the purchase of steers, which represents $53 \%$ of the total cost, followed by the purchase of fertilizers $(21 \%)$, land lease $(10 \%)$ and labor $(6 \%)$.

The cash flow amounts were updated to the prices of the 2016/2017 crop year (Table 5). An NPV of R\$16,696.16 (R\$ 2,782.69 per ha) and an IRR of $14 \%$ were reported, considering the prices of that agricultural year and the discount rate of $4.96 \%$. Therefore, the project proved to be economically attractive under these conditions. This result corroborated the findings on other studies on CLI systems. A rotation of pasture with soybean, rice and corn production reached IRR of $11.12 \%$ (MAGNABOSCO et al., 2009). LAZZAROTTO et al. (2010) analyzed a CLI system in Paraná, which considered the rotation of pasture with production of soybean and corn in the summer and wheat in the winter, and presented an IRR of $14.91 \%$. SILVA et al. (2012) reported IRR ranging from $3.6 \%$ to $4.8 \%$ in a study of CLI systems in the same state and with the same rotational procedure, but with different varieties of forage. Despite the differences on IRR, both studies concluded the financial results from CLI systems can be greater than specialized system on beef cattle or agricultural production due to lower vulnerability to variations on market and operational factors. LAZZAROTTO et al. (2010) compared CLI system result to conventional crop production (soybean production in the first season and corn production in the second season) and conventional beef cattle production under input-intensive system, which reached IRR of $13.99 \%$ and $14.95 \%$, respectively.

Table 6 presents the estimated cash flow of the CC system. The average of total cost in this system is $\mathrm{R} \$ 45,209.22$ ( $\mathrm{R} \$ 7,534.87$ per ha). The purchase of steers is the main cost ( $61 \%$ of the total cost), followed by the purchase of fertilizers $(16 \%)$, land lease $(9 \%)$ and labor (8\%). An NPV of R\$ 5,800.52 (R\$ 966.75 per ha) and an IRR of 9\% were reported, considering the prices of the 2016/2017 crop year and the discount rate of $4.96 \%$. Thus, CC system is also an economically attractive project; although, its NPV and IRR are smaller than the ones of CLI system.

The review of studies on conventional beef cattle systems showed several different values for IRR. Some of them are higher, while others are lower than the IRR estimated in the CLI system modeled in this article. In a medium-sized farm of 300 ha, beef cattle production system with $20 \%$ of pasture area managed intensively in input use showed IRR of $4.2 \%$ (IIS, 2015). An IRR of $6.87 \%$ was reported in a system with intensive management of pasture and feed supplementation (OLIVEIRA \& COUTO, 2018). HARFUCH et al. (2016) found an IRR of 
Table 5 - Cash flow of the CLI system (6 ha), in R\$.

\begin{tabular}{|c|c|c|c|c|c|c|}
\hline Item/year & Year 0 & Year 1 & Year 2 & Year 3 & Year 4 to 9 & Year 10 \\
\hline Selling of finished steers & - & $40,290.06$ & $34,136.84$ & $37,610.22$ & $37,345.71$ & $37,345.71$ \\
\hline Selling of corn silage & - & $9,059.6$ & $9,183.71$ & $11,556.58$ & $9,933.3$ & $9,933.3$ \\
\hline Residual value of infrastructure & - & - & - & - & - & $7,858.75$ \\
\hline Residual value of machines & - & - & - & - & - & 614.81 \\
\hline Investment & $32,079.52$ & - & - & - & - & - \\
\hline $\begin{array}{l}\text { Infrastructure (fences, salt and water } \\
\text { troughs, hydraulic material) }\end{array}$ & $24,680.02$ & - & - & - & - & - \\
\hline Liming (total area) & $1,251.4$ & - & - & - & - & - \\
\hline Machines and implements & $6,148.1$ & - & - & - & - & - \\
\hline Corn crop & - & $5,532.63$ & $5,532.63$ & $5,532.63$ & $5,532.63$ & $5,532.63$ \\
\hline Inputs & - & $5,318.63$ & $5,318.63$ & $5,318.63$ & $5,318.63$ & $5,318.63$ \\
\hline Corn seed & - & 482.8 & 482.8 & 482.8 & 482.8 & 482.8 \\
\hline Gliphosate herbicide & - & 207.2 & 207.2 & 207.2 & 207.2 & 207.2 \\
\hline NPK fertilizer (08-28-16) & - & $2,000.00$ & $2,000.00$ & $2,000.00$ & $2,000.00$ & $2,000.00$ \\
\hline NPK fertilizer (20-05-20) & - & $1,800.00$ & $1,800.00$ & $1,800.00$ & $1,800.00$ & $1,800.00$ \\
\hline Diesel and lubricants & - & 828.63 & 828.63 & 828.63 & 828.63 & 828.63 \\
\hline Labor & - & 214.01 & 214.01 & 214.01 & 214.01 & 214.01 \\
\hline Mechanical operations and silo & - & 214.01 & 214.01 & 214.01 & 214.01 & 214.01 \\
\hline Livestock production & - & $34,519.75$ & $27,822.17$ & $31,170.96$ & $31,170.96$ & $31,170.96$ \\
\hline Inputs - bovine & - & $26,790.32$ & $20,092.74$ & $23,441.53$ & $23,441.53$ & $23,441.53$ \\
\hline Steer & - & $25,120.00$ & $18,840.00$ & $21,980.00$ & $21,980.00$ & $21,980.00$ \\
\hline Vaccines & - & 75.04 & 56.28 & 65.66 & 65.66 & 65.66 \\
\hline Mineral mix & - & 234.05 & 175.54 & 204.79 & 204.79 & 204.79 \\
\hline Mineral/protein mix & - & 924.12 & 693.09 & 808.61 & 808.61 & 808.61 \\
\hline Tick insecticides & - & 281.07 & 210.81 & 245.94 & 245.94 & 245.94 \\
\hline Antihelminthics & - & 156.04 & 117.03 & 136.54 & 136.54 & 136.54 \\
\hline Inputs - pasture & - & $5,379.13$ & $5,379.13$ & $5,379.13$ & $5,379.13$ & $5,379.13$ \\
\hline Urea & - & $4,872.00$ & $4,872.00$ & $4,872.00$ & $4,872.00$ & $4,872.00$ \\
\hline Seeds Piatã grass & - & 152,00 & 152,00 & 152,00 & 152,00 & 152,00 \\
\hline Diesel and lubricants & - & 355.13 & 355.13 & 355.13 & 355.13 & 355.13 \\
\hline Labor & - & $2,350.3$ & $2,350.3$ & $2,350.3$ & $2,350.3$ & $2,350.3$ \\
\hline Animal management & - & $1,939.64$ & $1,939.64$ & $1,939.64$ & $1,939.64$ & $1,939.64$ \\
\hline Vaccination & - & 323.27 & 323.27 & 323.27 & 323.27 & 323.27 \\
\hline Mechanical operations & - & 87.39 & 87.39 & 87.39 & 87.39 & 87.39 \\
\hline Repairs and maintenance & - & 561,00 & 561,00 & 561,00 & 561,00 & 561,00 \\
\hline Salt and water troughs $(3 \%)$ & - & 202.21 & 202.21 & 202.21 & 202.21 & 202.21 \\
\hline Fence $(2 \%)$ & - & 358.79 & 358.79 & 358.79 & 358.79 & 358.79 \\
\hline Land lease & - & $4,260.00$ & $4,260.00$ & $4,260.00$ & $4,260.00$ & $4,260.00$ \\
\hline Cash flow & $-32,079.52$ & $4,476.28$ & $5,144.74$ & $7,642.2$ & $5,754.41$ & $14,227.97$ \\
\hline
\end{tabular}

Note. US Dollar quotation in the period 11.01.2016 to 11.01.2017 is R\$ $3.20=$ USD1.00 (Source: https://www4.bcb.gov.br/pec/taxas/port/ptaxnpesq.asp?id=txcotacao).

$9.2 \%$ in a $100 \%$ pasture system with a low level of input technology, while the IRRs in the same area, but with medium and high levels of input technology were $11.4 \%$ and $20.9 \%$, respectively. BARBIERI et al. (2016), in a study of feedlot system, reported a potential IRR of $10.91 \%$ in 4 years and $29.80 \%$ in 10 years.
The figures above allow us to point out that the CLI system modeled in this article is an attractive investment when compared to most non-integrated pasture management systems for raising cattle. It should be stressed that the risk and environmental benefits of CLI system were not considered in this analysis. 
MARTHA JUNIOR et al. (2011) argued that the positive economic performance of CLI can be explained by the effect of scope economy. Complementarity between corn and forage production lowers costs. The cost of pasture formation is decreased because intercropped seeding of corn and forage. Cost of labor and mechanized operation can also be reduced. In addition, soil quality and forage production increase due to the synergistic effect, which in turn positively affects beef cattle production (CARVALHO et al., 2018). Economies of scale may also arise in the CLI system, as pointed out by CARRER et al. (2020).

Figure 3 presents the frequency distribution of NPV for CLI system, which was obtained from the Monte Carlo simulation. The mean NPV is R\$16,696.60, and its minimum and maximum values are $-\mathrm{R} \$ 13,270.82$ and $\mathrm{R} \$$ $53,918.50$, respectively. The probability of an NPV greater than $\mathrm{R} \$ 16,696.16$ is $49.8 \%$ and probability of a negative NPV is $5.9 \%$. An NPV between zero and $\mathrm{R} \$ 16,696.16$ has $44.3 \%$ probability.

Figure 4 presents the frequency distribution of the NPV of the CC system, which was also obtained from the Monte Carlo simulation. The mean NPV is $\mathrm{R} \$ 5,986.71$, and its minimum and maximum values are $-\mathrm{R} \$ 10,154.55$ and $\mathrm{R} \$ 22,317.63$, respectively. The probability of an NPV greater than R $\$ 5,800.52$ is $48.5 \%$ and probability of a negative NPV is $16.6 \%$. An NPV between zero and R \$ 5,800.52 has 34.9\% of probability. These results indicated that the $\mathrm{CC}$ system has higher market risk than the CLI system.

Our findings corroborated other empirical studies carried out in other Brazilian regions

Table 6 - Cash flow of the CC system (6 ha), in R\$.

\begin{tabular}{|c|c|c|c|c|c|c|}
\hline Item/year & Year 0 & Year 1 & Year 2 & Year 3 & Year 4 to 9 & Year 10 \\
\hline Selling of finished steers & - & $57,425.22$ & $42,305.45$ & $49,574.91$ & $49,768.52$ & $49,768.52$ \\
\hline Residual value of infrastructure & - & - & - & - & - & $7,858.75$ \\
\hline Residual value of machines & - & - & - & - & - & 247.44 \\
\hline Investment & $31,660.87$ & - & - & - & - & - \\
\hline $\begin{array}{l}\text { Infrastructure(fences, salt and water } \\
\text { troughs, hydraulic material) }\end{array}$ & $24,680.02$ & - & - & - & - & - \\
\hline $\begin{array}{l}\text { Pasture recovery (herbicide, lime, } \\
\text { fertilizer, seed, labor, lubricant and } \\
\text { diesel) }\end{array}$ & $4,506.42$ & - & - & - & - & - \\
\hline Machines and implements & $2,474.44$ & - & - & - & - & - \\
\hline Livestock production & - & $42,620.75$ & $37,597.56$ & $40,946.35$ & $40,946.35$ & $40,946.35$ \\
\hline Input - bovine & - & $31,813.51$ & $26,790.32$ & $30,139.11$ & $30,139.11$ & $30,139.11$ \\
\hline Steer & - & $29,830.00$ & $25,120.00$ & $28,260.00$ & $28,260.00$ & $28,260.00$ \\
\hline Vaccines & - & 89.11 & 65.44 & 84.42 & 84.42 & 84.42 \\
\hline Mineral mix & - & 277.93 & 234.0 & 263.30 & 263.30 & 263.30 \\
\hline Mineral/protein mix & - & $1,097.39$ & 924.12 & $1,039.64$ & $1,039.64$ & $1,039.64$ \\
\hline Tick insecticides & - & 333.78 & 281.07 & 316.21 & 316.21 & 316.21 \\
\hline Antihelminthics & - & 185.30 & 156.04 & 175.55 & 175.55 & 175.55 \\
\hline Inputs - pasture & - & $7,308.00$ & $7,308.00$ & $7,308.00$ & $7,308.00$ & $7,308.00$ \\
\hline Urea & - & $7,308.00$ & $7,308.00$ & $7,308.00$ & $7,308.00$ & $7,308.00$ \\
\hline Labor & - & $3,499.24$ & $3,499.24$ & $3,499.24$ & $3,499.24$ & $3,499.24$ \\
\hline Animal management & - & $2,909.46$ & $2,909.46$ & $2,909.46$ & $2,909.46$ & $2,909.46$ \\
\hline Vaccination & - & 484.91 & 484.91 & 484.91 & 484.91 & 484.91 \\
\hline Mechanical operations & - & 104.87 & 104.87 & 104.87 & 104.87 & 104.87 \\
\hline Repairs and maintenance & - & 561.00 & 561.00 & 561.00 & 561.00 & 561.00 \\
\hline Salt and water trough $(3 \%)$ & - & 202.21 & 202.21 & 202.21 & 202.21 & 202.21 \\
\hline Fence $(2 \%)$ & - & 358.79 & 358.79 & 358.79 & 358.79 & 358.79 \\
\hline Land lease & - & $4,260.00$ & $4,260.00$ & $4,260.00$ & $4,260.00$ & $4,260.00$ \\
\hline Cash flow & $-31,660.87$ & $9,983.47$ & -113.12 & $3,807.55$ & $4,001.17$ & $12,107.37$ \\
\hline
\end{tabular}

Note. US Dollar quotation in the period 11.01.2016 to 11.01.2017 is R\$ $3.20=$ USD1.00 (Source:

https://www4.bcb.gov.br/pec/taxas/port/ptaxnpesq.asp?id=txcotacao).

Ciência Rural, v.51, n.2, 2021. 
(MAGNABOSCO et al., 2009; LAZZAROTTO et al., 2009; LAZZAROTTO et al., 2010; GARCIA et al., 2012; PACHECO et al., 2014; REIS et al., 2019). MAGNABOSCO et al. (2009) in an investigation of risk associated to CLI system under several scenarios (finished steer vs. bull sale; land lease vs. own land; own capital vs. rural credit), found the probability of negative NPV did not exceed 20\%. MARTHA JUNIOR et al. (2011) emphasized that the lower risk of the CLI system is a result of diversification.

The regression coefficients of the sensitivity analysis confirmed the impact of random variables on the economic performance of the CLI system. The coefficients of finished steer price, steer price and silage price were $1.42,-1.18$ and 0.76 , respectively. The great impact of finished steer price and steer price on economic performance corroborated other findings (ROSA et al., 2017). The identification of these sources of risk helps in the design of preventive strategies, such as the use of forward contracts for finished cattle (CARRER et al., 2013). Additionally, large amount of financial resource is required for acquisition of steers (MARTHA JÚNIOR et al., 2011), which can be a barrier for CLI system adoption. Therefore, credit supply policy would help in the diffusion of the system (CARRER et al., 2020).

\section{CONCLUSION}

The adoption of crop-livestock systems has been recommended for its environmental sustainability. In the Conference of the Parties (COP21, Paris, 2015), Brazil made a commitment to reduce in $37 \%$ its greenhouse gas emissions until 2025, and in $43 \%$ until 2030, basing itself on the emission levels of 2005. In the Brazilian Low-Carbon Agriculture Plan (ABC Plan), CLI systems were supported with the objective of contributing for the accomplishment of that commitment (MAPA, 2018). However, few studies examined the economic viability of these systems.

This paper presented an analysis on the economic viability of a CLI system using data from an experimental research carried out by EMBRAPA Pecuária Sudeste, Brazil. Rotation of corn with pasture for beef cattle production is the main characteristic of this system, which also presents environmental benefits. The NPV (R\$ 16,696.16; R\$ 2,782.69 per hectare) estimated for his system was positive for a hurdle rate of $4.96 \%$ and the estimated IRR was $14 \%$. Monte Carlo analysis indicated low probability (5.9\%) of a negative NPV. Therefore, CLI system presents economic attractiveness. Additionally, NPV and IRR estimated for the CLI system were higher than the ones estimated for a conventional cattle system. The Monte Carlo analysis showed that the CLI system presents lower market risk than the CC system. These findings are in accordance with others studies and are useful for policy strategies devoted to accelerate the diffusion of those systems.

The technical coefficients used in the analysis were obtained from a three-year experiment carried out in a single location, which is a limitation

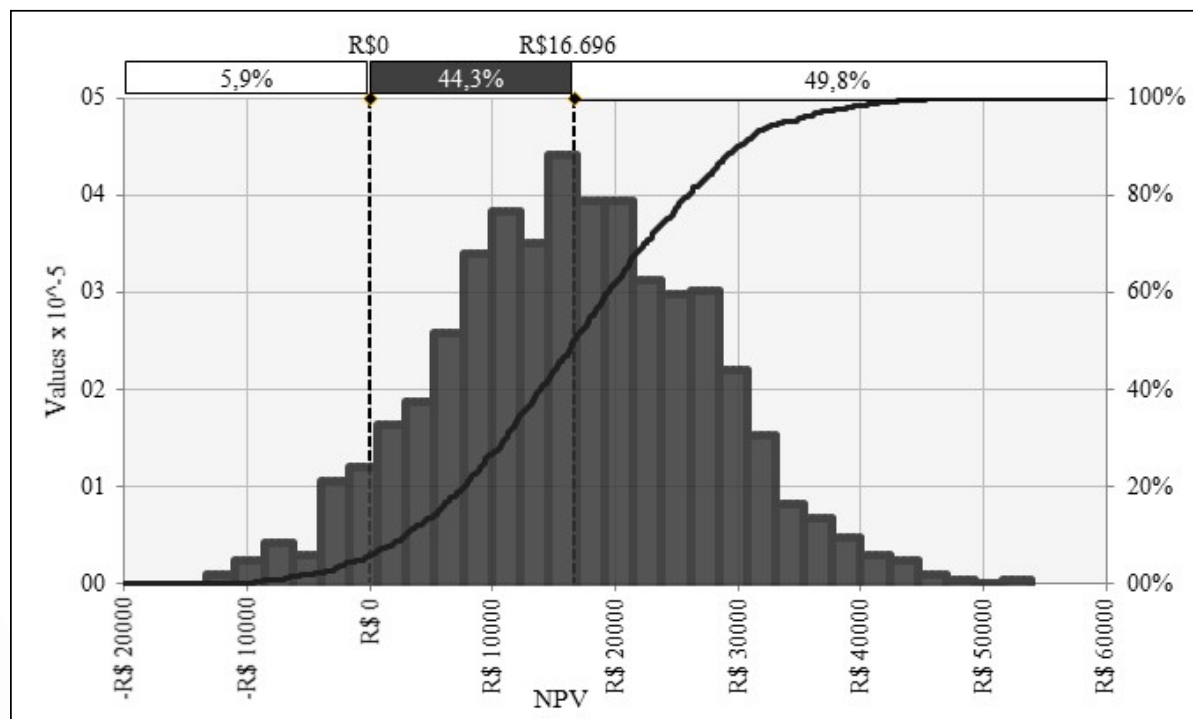

Figure 3 - Frequency distribution of NPV for CLI system resulting from Monte Carlo simulation. 


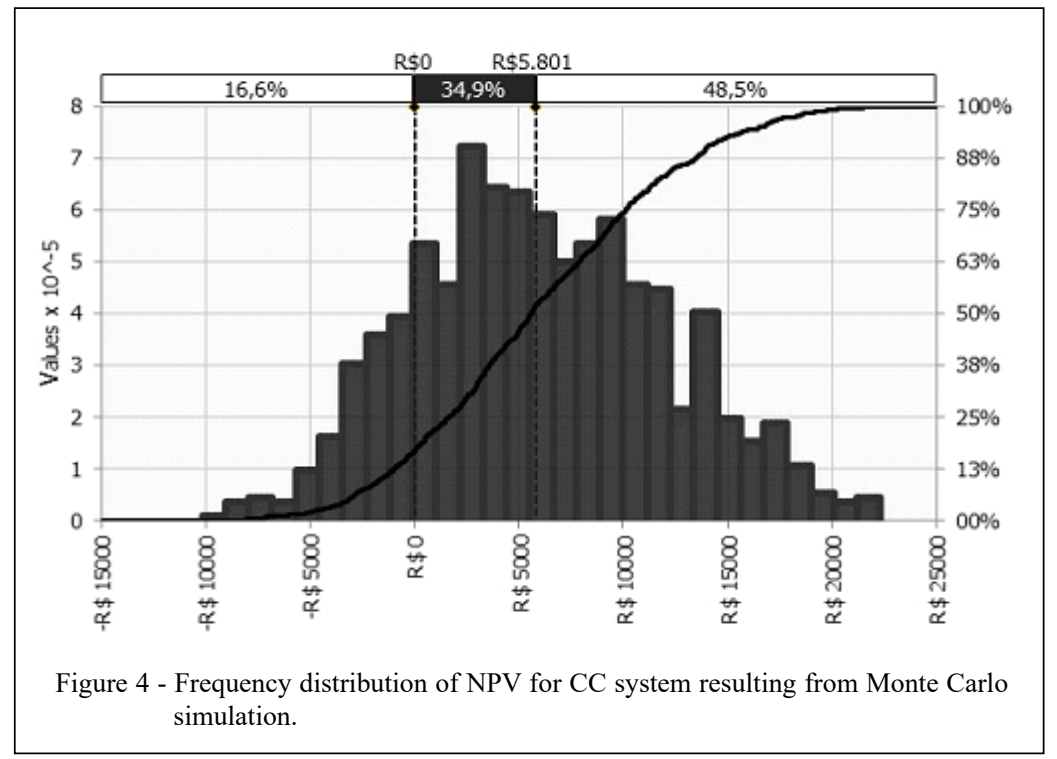

of this study. Long-term experiments and comparison of different experiments, in different locations, with different types of soil and climatic conditions, are recommended. Therefore, risks related to climatic conditions, pests and diseases can be assessed. Future studies on the economic evaluation of these systems could also evaluate the effect of other crops, such as sorghum and peanuts, in rotation with pasture.

\section{ACKNOWLEDGEMENTS}

To the Coordenação de Aperfeiçoamento de pessoal de Nível Superior (CAPES) for granting a Research Productivity Scholarship. To the Project "PECUS - Atlantic Forest" funded by Empresa Brasileira de Pesquisa Agropecuária (Embrapa code 01.10.06.001.05.01) and to the project "PECUS-REPENSA" fundend by Conselho Nacional de Desenvolvimento Científico e Tecnológico (CNPq code 562861/2010-6).

\section{DECLARATION OF CONFLICTS OF INTERESTS}

The authors declare no conflict of interest. The founding sponsors had no role in the design of the study; in the collection, analyses, or interpretation of data; in the writing of the manuscript, and in the decision to publish the results.

\section{AUTHORS' CONTRIBUTIONS}

The authors contributed equally to the manuscript.

\section{REFERENCES}

ANDRADE, C. M. S. et al. Plantio direto a lanço dos capins Xaraés e Piatã no Acre. Embrapa Acre-Comunicado Técnico (INFOTECA-E), 2015. Available from: < https://www.infoteca. cnptia.embrapa.br/infoteca/bitstream/doc/1032779/1/25833.pdf $>$. Accessed: Sep. 09, 2020.

BALBINO, L. C. et al. Evolução tecnológica e arranjos produtivos de sistemas de integração lavoura-pecuária-floresta no Brasil. Pesquisa Agropecuária Brasileira, v.46, n.10, p.00, out. 2011. Available from: <https://www.scielo.br/scielo. php?script $=$ sci_arttext\&pid $=$ S0100-204X2011001000001\&ln $\mathrm{g}=\mathrm{pt} \& \mathrm{t} \operatorname{lng}=\mathrm{pt}>$. Accessed: Sep. 09, 2020. doi: 10.1590/S0100204X2011001000001.

BARBIERI, R. S. et al. Economic viability analysis of feedlot beef cattle. Interações, v.17, n.3, p.357-369, 2016. Available from: $<$ https://www.scielo.br/scielo.php?pid=S1518$70122016000300357 \&$ script $=$ sci_arttext\&tlng $=\mathrm{pt}>$. Accessed: Sep. 09, 2020. doi: 10.20435/1984-042X-2016-v.17-n.3(01).

BEEFPOINT. Comprando e vendendo silagem de milho: Que valor é justo? Available from: <http://www.beefpoint. com.br/comprando-e-vendendo-silagem-de-milho-que-valor-ejusto-72788/>. Accessed: Nov. 20, 2017.

CARGNELUTTI FILHO, A. et al. Adjustments of probability distribution functions to global solar radiation in Rio Grande do Sul State. Pesquisa Agropecuária Brasileira, v.39, n.12, p.1157-1166, 2004. Available from: <https://www.scielo.br/ scielo.php? pid $=\mathrm{S} 0100-204 X 2004001200001 \& \mathrm{script}=\mathrm{sci}$ arttext>. Accessed: Sep. 09, 2020. doi: 10.1590/S0100204X2004001200001.

CARRER, M. J. et al. Factors influencing beef cattle farmers use of risk management instruments in the State of São Paulo, Brazil. Ciência Rural, v.43, n.2, p.370-376, 2013. Available from: <https://www.scielo.br/scielo.php?pid=S0103$84782013000200030 \&$ script $=$ sci arttext\&tlng $=\mathrm{pt}>$. Accessed: Sep. 09, 2020. doi: 10.1590/S0103-84782013000200030.

CARRER, M. J. et al. Assessing the effectiveness of rural credit policy on the adoption of integrated crop-livestock systems in Brazil. Land Use Policy, v.92, 2020. Available from: $<$ https://www.

Ciência Rural, v.51, n.2, 2021. 
sciencedirect.com/science/article/abs/pii/S0264837718313838>. Accessed: Sep. 10, 2020. doi: 10.1016/j.landusepol.2020.104468.

CARVALHO, P. C. F. et al. Animal production and soil characteristics from integrated crop-livestock systems: toward sustainable intensification. Journal of animal science, v.96, n.8, p.3513-3525, 2018. Available from: <https://www.ncbi.nlm.nih. gov/pmc/articles/PMC6095278/>. Accessed: Sep. 10, 2020. doi: 10.1093/jas/sky085.

CASAROTTO FILHO, N.; KOPITTKe, B. H. Análise de investimentos: matemática financeira, engenharia econômica, tomada de decisão, estratégia empresarial. São Paulo: Atlas, 2000.

CEPEA. Série de preços do boi gordo e do milho. Available from: $<$ https://www.cepea.esalq.usp.br/br>. Accessed: Nov. 20, 2017.

FIGUEIREDO, A. M. et al. Integração na criação de frangos de corte na microrregião de Viçosa-MG: viabilidade econômica e análise de risco. Revista de Economia e Sociologia Rural, v.44, n.4, p.713-730, 2006. Available from: <https://www.scielo. br/scielo.php?pid $=$ s0103-20032006000400005\& script $=$ sci arttext>. Accessed: Sep. 10, 2020. doi: 10.1590/S010320032006000400005.

GARCIA, C. M. P. et al. Economic analysis of grain yield of maize intercropped with forage plants of the genera Brachiaria and Panicum in no-tillage system. Revista Ceres, v.59, n.2, p.157-163, mar/abr. 2012. Available from: $<$ https:// www.scielo.br/scielo.php? script $=$ sci arttext\&pid $=S 0034$ 737X2012000200002>. Accessed: Sep. 09, 2020. doi: 10.1590/ S0034-737X2012000200002

HARFUCH, L. et al. Economic analysis of investment for the cattle ranching expansion. São Paulo: INPUT \& AGROICONE, 2016.

INSTITUTO DE ECONOMIA AGRÍCOLA (IEA). Preços médios mensais pagos pela agricultura e Preços médios mensais recebidos pelos agricultores. Available from: <http://www.iea. agricultura.sp.gov.br/out/Bancodedaos2.html >. Accessed: Nov. 20, 2017.

INTERNATIONAL INSTITUTE FOR SUSTAINABILITY (IIS). Análise econômica de uma pecuária mais sustentável. Rio de Janeiro: International Institute for Sustainability, 2015.

KAMALI, F. P. et al. Environmental and economic performance of beef farming systems with different feeding strategies in southern Brazil. Agricultural Systems, v.146, p.70-79, 2016. Available from: <https://www.sciencedirect.com/science/article/abs/pii/ S0308521X16300634>. Accessed: Sep. 09, 2020. doi: 10.1016/j. agsy.2016.04.003.

LAZZAROTTO, J. J. et al. Volatilidade dos retornos econômicos associados à integração lavoura-pecuária no Estado do Paraná Revista de Economia e Agronegócio, v.7, n.2, p.259-283, 2009. Available from: <https://www.locus.ufv.br/bitstream/ handle $/ 123456789 / 20085 /$ artigo.pdf? sequence $=1$ \& is Allowed $=y>$. Accessed: Sep. 09, 2020.

LAZZAROTTO, J. J. et al. Financial viability and risks of integrated crop-livestock systems in the state of Paraná. Organizações Rurais \& Agroindustriais, v.12, n.1, 2010. Available from: $<$ https://ageconsearch.umn.edu/record/93585>. Accessed: Sep. 09, 2020. doi: 10.22004/ag.econ.93585.
MACEDO, M. C. M. Crop and livestock integration: the state of the art and the near future. Revista Brasileira de Zootecnia, Campo Grande, v.38, n.1, p.133-146, 2009. Available from: <https://www.scielo.br/scielo.php?pid=S151635982009001300015\&script=sci_arttext\&tlng=ES>. Accessed: Sep. 09, 2020. doi: 10.1590/S1516-35982009001300015.

MACEDO, C. A. A. et al. Analysis of economic and financial viability and risk evaluation of a wind project with Monte Carlo simulation. Gestão e Produção, v.24, n.4, p.731-744, 2017. Available from: <https://www.scielo.br/scielo.php?pid=S0104530X2017000400731\&script=sci_arttext $>$. Accessed: Sep. 09, 2020. doi: 10.1590/0104-530x3439-16.

MAGNABOSCO, C. U. et al. Economic and Risk Analysis of Crop Livestock Integration in Goias State. Embrapa CerradosBoletim de Pesquisa e Desenvolvimento (INFOTECA-E), 2009. Available from: $<$ https://ainfo.cnptia.embrapa.br/digital/bitstream/ CPAC-2010/31948/1/bolpd-261.pdf>. Accessed: Sep. 09, 2020.

MARTHA JÚNIOR, G. B. et al. Economic dimension of integrated crop-livestock systems, Pesquisa Agropecuária Brasileira, v.46, n.10, p.1117-1126, out. 2011. Available from: <https://www.scielo. br/scielo.php?pid $=$ S0100-204X2011001000002\&script $=$ sci arttext $>$. Accessed: Sep. 10, 2020. doi: 10.1590/S0100204X2011001000002.

MARTINELLI, G. C. et al. Decreasing uncertainties and reversing paradigms on the economic performance of agroforestry systems in Brazil. Land Use Policy, v.80, p.274-286, 2019. Available from: $\quad<\mathrm{https}: / /$ www.sciencedirect.com/science/article/pii/ S026483771830423X>. Accessed: Sep. 10, 2020. doi: 10.1016/j. landusepol.2018.09.019.

MOORE, J. H.; WEATHERFORD, L. R. Tomada de decisões em administração com planilhas eletrônicas. Porto Alegre: Bookman, 2005.

MOTTA, R. R.; CALÔBA, G. M. Análise de investimentos: tomada de decisão em projetos industriais. São Paulo: Atlas, 2002.

NORONHA, J. F.; DUARTE, L. P. Avaliação de projetos de investimentos na empresa agropecuária. In: AIDAR, A. C. K. (Ed.). Administração Rural. São Paulo: Paulicéia, 1995, p. 213-251.

OLIVEIRA, E. R.; COUTO, V. R. M. Productive and Economic Viability of Raising Beef Cattle in the Savanna of the Brazilian State of Goiás. Revista de Economia e Sociologia Rural, v.56, n.3, p.395-410, 2018. Available from: <https://www.scielo. br/scielo.php?pid $=$ S0103-20032018000300395\&script $=$ sci arttext $>$. Accessed: Sep. 10, 2020. doi: 10.1590/1234-5678180694790560302.

PACHECO, P. S. et al. Use of the correlation between input variables in estimating the risk of feedlot finishing of steers and young steers. Anais da Academia Brasileira de Ciências, v.86, n.2, p.945-954, 2014. Available from: <https://www.scielo.br/ scielo.php?script=sci_arttext\&pid=S0001-37652014000200945>. Accessed: Sep. 10, 2020. doi: 10.1590/0001-37652014110012.

PACHECO, P. S. et al. Stochastic simulation of the economic viability of feedlot finishing steers slaughtered at different weights in southern Brazil. Bioscience Journal, v.33, n.3, p.652659, 2017. Available from: <http://www.seer.ufu.br/index.php/ biosciencejournal/article/view/34110>. Accessed: Sep. 10, 2020. doi: 10.14393/BJ-v33n3-34110. 
REIS, J. C. et al. Assessing the economic viability of integrated crop- livestock systems in Mato Grosso, Brazil. Renewable Agriculture and Food Systems, p.1-12, 2019. Available from: $<$ https://www.cambridge.org/core/journals/renewable-agricultureand-food-systems/article/assessing-the-economic-viabilityof-integrated-croplivestock-systems-in-mato-grosso-brazil/ B3146D09A5B5B61567CDC4E1874E7988\#>. Accessed: Sep. 10, 2020. doi: $10.1017 / \mathrm{S} 1742170519000280$.

RICHARDSON, J. W. et al. A financial assessment of two alternative cultivation systems and their contributions to algae biofuel economic viability. Algal Research, V.4, P. 96-104, 2014. Available from: <https://www.sciencedirect.com/science/ article/pii/S2211926413001215>. Accessed: Sep. 10, 2020. doi: 10.1016/j.algal.2013.12.003.

ROSA, J. R. P. et al. Risk analysis of the economic viability of feedlot Aberdeen Angus steers fed with different proportions of concentrate. Bioscience Journal, V.33, N.3, P.660-669, 2017. Available from: <http://www.seer.ufu.br/index.php/ biosciencejournal/article/view/34547>. Accessed: Sep. 10, 2020. doi: 10.14393/BJ-v33n3-34547.

SANTOS, G. J.; MARION, J. C. Administração de custos na agropecuária. São Paulo: Atlas, 1996.
SCOT CONSULTING. Série de preços do garrote. Available from: $\quad<$ https://www.scotconsultoria.com.br/cotacoes/ reposicao/?ref=smn>. Accessed: Nov. 20, 2017.

SILVA, H. A. et al. Economic viability of dairy heifer production on pasture in crop-livestock integration system. Pesquisa Agropecuária Brasileira, v.47, n.6, p.745753, jun. 2012. Available from: <https://www.scielo.br/ scielo.php?pid=S0100-204X2012000600003\&script $=$ sci arttext\&tlng=pt $>$. Accessed: Sep, 09, 2020. doi: 10.1590/ S0100-204X2012000600003.

SOUZA FILHO, H. M. et al. Análise da competitividade da cadeia produtiva da carne bovina do Estado de São Paulo. Informações Econômicas, v.40, n.3, p.16-28. 2010. Available from: <http:// www.iea.sp.gov.br/out/LerTexto.php? $\operatorname{codTexto}=11867>$. Accessed: Sep. 10, 2020.

ZYLBERSZTAJN, D.; MACHADO FILHO, C. P Competitiveness of meat agri-food chain in Brazil. Supply Chain Management: An International Journal, v.8, n.2, p.155-165, 2003. Available from: <https://www.emerald. com/insight/content/doi/10.1108/13598540310468751/ full/html $>$. Accessed: $\quad$ Sep. 10, 2020. doi: $10.1108 / 13598540310468751$ 